\title{
An investigation on the relationship between critical thinking skills, language learning strategies, and thinking styles of Iranian EFL learners
}

\author{
Alimirzaloo, Elham \\ Department of English Language and Literature, Islamic Azad University, Ahar Branch, Ahar, Iran \\ (alimirzalooelham@yahoo.com) \\ Hashemnezhad, Hossein \\ Assistant Professor of TEFL, EFL Department, Islamic Azad University, Khoy Branch, Khoy, Iran \\ (h_hashemnezhad2000@yahoo.com)
}

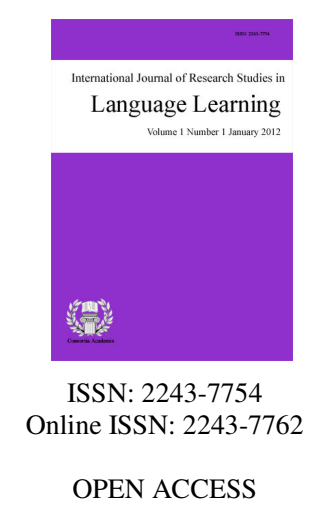

Received: 13 February 2015

Revised: 16 March 2015 DOI: $10.5861 /$ ijrsll.2015.1106

Accepted: 20 April 2015

\section{Abstract}

This study was an attempt to explore the relationship between and among three variables of critical thinking, language learning strategies and thinking styles. To this end, three sets of questionnaires, namely, the Sternberg and Zhang (1991) thinking styles inventory questionnaire, California critical thinking questionnaire as well as Oxford's (1990) language learning strategies were utilized as the instruments to elicit the required data from the selected 60 participants. The data was coded and put into SPSS 22 which was analyzed using Spearman's rank order correlation (Rho) as well as multiple regression analysis. The results of the study indicated that there is significant relationship between critical thinking and thinking styles as well as between language learning strategies and thinking styles. However, the results of the study found non-significant relationship between critical thinking and thinking styles, the results of the multiple regression analysis indicated significant relationships among the three variables. Hence, it seems that language learning strategies play the interfacing role between critical thinking and thinking styles since language learning strategies were showed to be significantly correlated with both critical thinking and thinking styles. Furthermore, non-significant relationship was found between critical thinking and thinking styles, however, the results of multiple regression analysis showed significant correlation among the three variables.

Keywords: critical thinking; thinking styles; language learning strategies; multiple regression analysis; Spearman's rank order correlation 


\section{An investigation on the relationship between critical thinking skills, language learning strategies, and thinking styles of Iranian EFL learners}

\section{Introduction}

Critical Thinking, according to Ruggiero (1989), refers to the reflective thinking in which the focus is given to interpret, analyze, criticize, synthesize, and evaluate information, arguments and experiences resorting to a set of reflective attitudes, skills, and abilities to direct thoughts, beliefs, and actions. There is no doubt that the ability to think critically is crucial for solving diverse problems not only in the academic contexts but also in the applied situations. Recently, critical thinking has attracted the attention of many wise researchers who are interested in the potentials of critical thinking in the domains of teaching and learning. Hence, there are many debates regarding the exact definition of what critical thinking skills mean. Watson and Glaser (1980) define critical thinking as "a bundle of skills, knowledge, and attitudes which enables the individuals in making inferences, deductions, interpretations, recognizing the assumptions, as well as evaluating the arguments" (p. 134).

It is worth mentioning that some scholars tend to use critical thinking and higher order thinking interchangeably (Halpern, 1998). Whereas, some other scholars prefer a sharp distinction between critical thinking and higher order thinking (Facione, 1990). In effect, the relationships which exist among different concepts like 'critical thinking', 'higher order thinking', 'thinking skills' and other terms such as 'informal logic', 'informal reasoning', 'problem solving', 'argumentation', 'critical reflection', 'reflective judgment', as well as 'metacognition' are among the issues which have complicated the studies dealing with critical thinking.

Two of the issues seem to be reflected in critical thinking are the issues of the styles of thinking and learning strategies. In effect, critical thinking which is assumed to be a higher order of thinking is reflected in diverse thinking styles in a variety of complex ways. One of the recent theories in terms of thinking styles was introduced by Sternberg's $(1988,1997)$ which attracted the attention of many scholars. Sternberg's theory argued about thirteen styles for thinking (i.e. Legislative, Executive, Judicial, Hierarchic, Monarchic, Oligarchic, Anarchic, Global, Local, Internal, External, Liberal, and Conservative). Furthermore, in terms of learning strategies, Naiman, Frohlich, Stern, and Todesco (1978) argued about the significant role played by various learning strategies in being a good language learner. In effect, they stressed that there are factors other than language aptitude and motivation as effective factors for success of language learners. Naiman et al. (1978) added that learners are actively participating the process of language learning deploying specific individualized learning techniques named learning strategies.

One of the main purposes of every teacher is to equip the students with the required resources to understand the content of the materials being taught in the class, and even to help them to become independent problem solvers (Bransford, Brown, \& Cocking, 2000). Hence, three major factors that seem to play a role in this process are student thinking styles; critical thinking skills and students' learning strategies .However, many scholars tried to investigate the relationship between critical thinking and thinking styles or critical thinking and learning strategies; few studies, if any, tried to shed light on the relationship among critical thinking, thinking styles and learnings strategies. To this end, Sternberg's $(1988,1997)$ theory of thinking styles and California's critical thinking questionnaires as well as Oxford's (1990) language learning strategies will be utilized as three main instruments which will be filled out by 30 female and 30 male students majoring English.

Effectively, it was discussed by some researchers (e.g. Nikoopour, Farsani \& Nasiri, 2010) that there is a significant relationship between using language learning strategies and thinking — critical or non-critical. Hence, this issue seems to influence the success of language learners in the challenging process of foreign language learning. Furthermore, many studies (e.g. Negari \& Solaymani, 2013) indicated that there is a significant 
The relationship between critical thinking skills, language learning strategies, and thinking styles

relationship between all the subcategories of language learning and thinking styles with the autonomy of language learning which influence language learning success. Hence, it is not surprising that there is a positive relationships between critical thinking and learning strategies, critical thinking and thinking styles, and among critical thinking, learning strategies and thinking styles. It means that these three elements influence language learning positively.

\subsection{Significance of the Study}

One of the main purposes of any instructional course is to assist the students to improve their understanding of the materials taught in such a way that the students become more independent. To this end, many studies have been performed which resulted in the strong effect of critical thinking or thinking styles or learning strategies on students learning (e.g. Cano, 1993, 1999; Cano \& Garton, 1994; Cano \& Martinez, 1991; Cano \& Metzger, 1995; Cano \& Torres, 1994, 1995; Dyer, 1995; Dyer \& Osborne, 1996a, 1996b; Garton, Lamberson, Spain, \& Spiers, 1999; Ricketts, 2003, and many others); however few studies, if any, has tried to investigate the relationships between and among critical thinking, thinking styles, learning strategies which seems to play a crucial role on learning needs to be considered.

Focusing on the relationship between and among critical thinking, thinking styles and learning strategies seem to be significant not only for EFL students but also for language teachers, syllabus designers as well as teachers' trainers. It may shed light on the need and importance of critical thinking as a crucial element correlated with thinking styles as well as learning strategies which seem to be a requisite for being a successful language learners in using language which in its turn influence the performance of the teachers or teachers' trainers as well as syllabus designers in order to organize the syllabus in such a way to consider the roles played by critical thinking, thinking styles or learning strategies.

\subsection{Purpose and Scope of the Study}

This study attempted to determine the relationship between Iranian EFL student learning styles, their critical thinking skills, and their language learning strategies. Effectively, the objectives of this study were as follows:

$>\quad$ To describe the thinking styles, language learning strategies and critical thinking skills of Iranian EFL students.

$>\quad$ To determine the relationships between and among the thinking styles, language learning strategies and critical thinking skills of Iranian EFL students

Determining the relationships between and among three variables of critical thinking, language learning strategies and thinking styles; it becomes apparent that there is a positive relationship between a particular thinking style, level of critical thinking and language learning strategies. Accordingly, equipping the teachers with this knowledge may help her/him to improve his teaching performances as well as the achievements of the students.

\subsection{Research Questions}

In order to determine the relationship between and among critical thinking, thinking styles and language learning strategies, the study aims to answer the following questions:

$>$ Are there any relationship between critical thinking and language learning strategies?

$>$ Are there any relationship between critical thinking and thinking styles?

$>$ Are there any relationship between thinking styles and language learning strategies?

$>$ Are there any relationship between thinking styles, critical thinking and language learning strategies? 
Based on the raised questions the following hypotheses were suggested:

There is a relationship between critical thinking and language learning strategies.

$>$ There is a relationship between critical thinking and thinking styles.

$>$ There is a relationship between language learning strategies and thinking styles.

$>$ There is a relationship between critical thinking, language learning strategies and thinking styles.

\section{Review of Literature}

\subsection{Critical Thinking: Theoretical Studies}

Critical thinking has rooted in three main academic disciplines, i.e. philosophy, psychology and education (Lewis \& Smith, 1993; Sternberg, 1986). The philosophical school of critical thinking has focused on the hypothetical critical thinker in which its main objective is to enumerate the qualities and characteristics of that person (Lewis \& Smith, 1993; Thayer-Bacon, 2000). In fact, this perspective of critical thinking does not consider the behaviors or actions performed by the critical thinker (Lewis \& Smith, 1993; Thayer-Bacon, 2000); instead, it considers critical thinker as an ideal person for weighting the capabilities of people under the best circumstances (Sternberg, 1986).

Every domains of critical thinking has raised diverse definitions for critical thinking. The following sheds light on some of these definitions:

$>\quad$ “The propensity and skill to engage in an activity with reflective skepticism" (McPeck, 1990, p. 8);

$>\quad$ "Reflective and reasonable thinking that is focused on deciding what to believe or do" (Ennis, 1985, p. $45)$;

$>\quad$ "Skillful, responsible thinking that facilitates good judgment because it 1) relies upon criteria, 2) is self-correcting, and 3) is sensitive to context" (Lipman, 1988, p. 39);

$>$ "purposeful, self-regulatory judgment which results in interpretation, analysis, evaluation, and inference, as well as explanation of the evidential, conceptual, methodological, criteriological, or conceptual considerations upon which that judgment is based" (Facione, 1990, p. 3);

$>$ "Disciplined, self-directed thinking that exemplifies the perfections of thinking appropriate to a particular mode or domain of thought" (Paul, 1992, p. 9);

$>$ Thinking that is goal-directed and purposive, "thinking aimed at forming a judgment," where the thinking itself meets standards of adequacy and accuracy (Bailin, Case, Coombs, \& Daniels, 1999, p. 287); and

$>$ "Judging in a reflective way what to do or what to believe" (Facione, 2000, p. 61).

The second school of critical thinking is cognitive psychological approach which emphasizes on the way people think as well as the types of actions or behaviors critical thinkers can do (Sternberg, 1986). Lewis and Smith (1993) clarify that cognitive psychological approach considers critical thinking according to a list of skills or procedures which a critical thinker can do. Cognitive psychological approach to critical thinking, in a similar vein, has provided a number of different definitions for critical thinking as follow:

$>\quad$ the mental processes, strategies, and representations people use to solve problems, make decisions, and learn new concepts" (Sternberg, 1986, p. 3); 
The relationship between critical thinking skills, language learning strategies, and thinking styles

$>$ "the use of those cognitive skills or strategies that increase the probability of a desirable outcome" (Halpern, 1998, p. 450); and

$>$ "seeing both sides of an issue, being open to new evidence that disconfirms your ideas, reasoning dispassionately, demanding that claims be backed by evidence, deducing and inferring conclusions from available facts, solving problems, and so forth" (Willingham, 2007, p. 8).

The last school in the domain of critical thinking is educational orientation which has primarily focused on the taxonomy for information processing skills. In effect, most studies trying to deal with critical thinking are using the Bloom's taxonomy which is composed of diverse levels for raising critical thinking, i.e. remembering, understanding, applying, analyzing, evaluating and creating.

\subsection{Thinking Styles}

Thinking styles, in effect, involve intellectual styles compose of cognitive styles, learning styles and problem-solving styles (Zhang \& Sternberg, 2006). Hence, thinking style sheds light on the capacity of the people to process information and deal with life events. Zhang and Sternberg (2006) emphasize that thinking style is a more general concept comparing learning or cognitive style.

It is worth mentioning that cognitive, learning and thinking styles are over lapping terms since all of them are applied for processing the same information (Zhang \& Sternberg, 2006). In effect, cognitive style deals with the ways through which an individual prefers to conceive information, learning style with the ways through which an individual prefers to learn that information; and thinking style with the way through which an individual to think about the information during and after learning process (Zhang \& Sternberg, 2006).

Generally speaking, thinking styles or intellectual styles in Zhang and Sternberg's (2005) terminology is an umbrella term covering all style constructs which shed light on the individual's preference for processing information. Zhang, Sternberg, and Rayner (2012, p. 1) emphasize that "different scholars have their own preferred style terms, both in their writings and in the talks they deliver, including "cognitive style," "learning style," "thinking style," "mind style," "mode of thinking," or "teaching style".

Thinking style, according to Sternberg (1997) tries to answer the following questions:

Why do some people turn to law, others to medicine, and still others to accounting? And why do some of those doctors who were straight-A students in medical school fail their patients? Why it is that some gifted kid's get straight A's in school, whereas others with equal abilities flunk out? These are just some of the questions that can be addressed through an understanding of styles of thinking (p. 18).

Intellectual styles is a term which was firstly introduced by Zhang and Sternberg (2005) in their Threefold Model of Intellectual Styles. Hence, diverse models were emerged to deal with the intellectual styles (e.g. Curry's (1983) "onion" model of learning styles; Miller's (1987) model of cognitive processes and styles; Riding and Cheema's (1991) model of cognitive styles; Grigorenko and Sternberg's (1995) model of style traditions; Zhang and Sternberg's (2005) threefold model of intellectual styles; and Sadler-Smith's (2009) duplex model of cognitive style.

Curry's (1983) model, in effect, has organized different styles into nine learning-style measures (later expanded to 21 inventories). In effect, the diverse styles proposed by Curry were organized into three layers resembling the layers of an onion. Hence, Curry considers three layers of personality, information processing and instructional preferences. Curry (1983) argues that learning is manipulated by styles which are grounded in the deep structure of personality, manipulated through information-processing styles, and finally, interact with instructional preferences. Rayner and Riding (1997) mentioned that the onion model has integrated cognition, personality, and activity. 
Miller's (1987) Model of Cognitive Processes and Styles, on the other hand, considers intellectual or cognitive styles to be composed of three fundamental types of cognitive processes, i.e. perception, memory, and thought which are the root of individual differences. Miller has categorized all cognitive styles under analytic-holistic dimension which contributed to individual difference in cognitive processing. Hence, Miller's (1987) model has made association between styles and cognitive processes. It is worth mentioning that Miller, later, incorporated other dimensions, i.e. personality typology of cognitive, affective, and conative to his original model in 1991.

Riding and Cheema's (1991) Model of Cognitive Styles, following a new perspective, considers all intellectual styles under two main two main cognitive-style dimensions of wholist-analytic and verbal-imagery. The first dimension sheds light on the fact that whether an individual tends to process information in wholes or in parts; and the second dimension on the preferences of the individuals to an individuals to represent information verbally or pictorially. While, Grigorenko and Sternberg's (1995) Model of Style Traditions, in a similar vein, consider three dimensions of cognition, personality and activity to be linked. Hence, they argue that the three classification of cognition, personality and activity directly shed light on the long-standing issue of the styles under the abilities and personality.

Zhang and Sternberg's (2005) Threefold Model of Intellectual Styles has adopted an open system in which any individual model can be incorporated. Hence, Zhang and Sternberg's (2005) Threefold Model considers Type I, Type II, and Type III intellectual styles in which

Type I styles tend to be more creativity generating and denote higher levels of cognitive complexity"; "Type II styles suggest a norm-favoring tendency and denote lower levels of cognitive complexity". And "Type III styles may manifest the characteristics of either Type I or Type II styles, depending upon the stylistic demands of the specific task being dealt with" (Zhang, Sternberg, \& Rayner, 2012, p. 12).

Finally, Sadler-Smith's (2009) Duplex Model of Cognitive Style is working based on dual-process theory and Cognitive-Experiential Self-Theory. Sadler-Smith (2009) stress on two main information-processing modes used during decision making and problem solving, namely, intuitive and analytic. Whereas, intuitive mode which is laden mainly by affect is operationally fast and structurally slow, imagery-based and unconscious; analytic mode is operationally slow, structurally fast, symbolic-based and conscious. Hence, Sadler-Smith's (2009) Duplex Model has considered a connection between field of styles and cognitive psychology.

\subsection{Language Learning Strategies}

Learning strategy, according to Wenden (1987, pp. 7-8) refers to the "the various operations that learners use in order to make sense of their learning". Oxford (1990) argues about twelve key features of language learning strategies as follow:

$>$ Contribute to the main goal, communicative competence;

$>$ Allow learners to become more self-directed;

$>$ Expand the role of teachers;

$>$ Are problem oriented;

$>$ Are specific actions taken by the learner;

$>$ Involve many aspects of the learner, not just the cognitive;

> Support learning both directly and indirectly;

$>$ Are not always observable;

$>$ Are often conscious ; 
$>$ Can be taught ;

$>$ Are flexible;

$>$ Are influenced by a variety of factors; (Oxford, 1990, p. 9)

Many scholars in the field of learning strategies classified diverse strategies-e.g. O'Malley and Chamot (1990), Oxford (1990). Rubin (1987) considers three types of strategies used by learners, namely, learnings strategies, communications strategies and social strategies. Learning Strategies composed of two sub-categories of Cognitive and Metacognitive Learning Strategies. Cognitive Learning Strategies (CLS) refer to the processes used by the language learner in learning or problem-solving tasks which demand analyzing, transforming, or synthesizing learning materials.

Rubin (1987) argues about six main cognitive learning strategies which are directly associated with language learning, i.e. Clarification/Verification, Guessing/Inductive, Inferencing, Deductive Reasoning, Practice, Memorization, and Monitoring. Communication Strategies, less directly related to language learning, are utilized by interlocutors in facing with misconception by a co-interlocutor. Social Strategies are utilized, on the other hand, in the situations when the learners are engaged in tasks in which the learners need to use their knowledge in real-like situations. O'Malley et al. (1985), in a similar vein, consider three main subcategories for language learning strategies, i.e. Metacognitive Strategies, Cognitive Strategies, and Socio-affective Strategies. Cognitive Strategies, on the other hand, are related to particular learning tasks and the manipulation of the learning material itself (O'Malley et al, 1985). The Socio-affective Strategies, particularly, deals with the interaction with another person in conducting diverse tasks (O’Malley et al., 1985).

Oxford's (1990) classification which is the main focus of the present study has provided the most comprehensive classification of language learning strategies. In effect, Oxford (1990) considers two types of learnings strategies, i.e. direct and indirect which they have some sub-classes. In effect, direct strategy has composed of memory, cognitive and compensation; and the indirect one of metacognitive, affective and social. It was mentioned that learning strategies are composed of two main types of direct and indirect. Direct strategies refers to the mechanisms by which target language is directly used to facilitate language learning. Oxford (1990) has divided direct strategies into three subcategories of Memory, Cognitive and Compensation Strategies.

Memory Strategies, according to Oxford, Lavin and Crookall (1989) refer to the "techniques specifically tailored to help the learner store new information in memory and retrieve it later" (p. 404). Hence, memory strategies are beneficial in vocabulary learning which is "the most sizable and unmanageable component in the learning of any language" (Oxford, 1990, p. 39). Compensation Strategies, on the other hand, refer to the strategies which learners utilize in comprehending or producing the target language in which they have some limitations (Oxford, 1990). For example, when learners are confronted with unknown expressions, they may resort to the guessing strategies, which are also known as inferencing. The second group of strategies provided by Oxford (1990) is indirect strategies which are composed of three subcategories of Metacognitive, Affective, and Social Strategies.

\subsection{Empirical studies}

Myers and Dyer (2006) made an investigation on the relationship between student learning style and their critical thinking skill. In effect, Myers and Dyer (2006) attempted to investigate the influence of students' learning styles on their critical thinking. To this end, they selected 135 students who enrolled in a college of agriculture and life sciences leadership development course at the University of Florida as the subjects of their study. Their results indicate to no critical thinking skill differences between male and female students in this study. Furthermore, they showed that "students with deeply embedded Abstract Sequential learning style preferences exhibited significantly higher critical thinking skill scores" (Myers \& Dyer, 2006, p. 43).

Abdi (2012) made a study to investigate the relationship between thinking styles and critical thinking skills among 207 university students who were selected through multi-stage cluster sampling. To this end, he applied 
Sternberg and Wagner's (1992) thinking styles for assessing students' thinking styles. Furthermore, California critical thinking skills' Test B form were utilized to assess their critical thinking skills. The results indicated that there was a significance relationship between thinking styles and critical thinking skills. In addition, a positive and meaningful correlation was found between executive thinking style and the total scores of critical thinking skills. It is worth mentioning that, Abdi did not found any significance relationship between Executive thinking style with evaluation and analysis components of critical thinking skills.

Mohammadi, Heidari, and Niry (2012) made an investigation to determine the relationship between critical thinking ability and reading strategies used by Iranian EFL learners.to this end, they selected 75 Iranian EFL senior students (35 males and 40 females) majoring in English Literature and Translation two sets of questionnaires, i.e. a critical thinking questionnaire and a reading strategy questionnaire were filled out by the subjects. Their investigation showed that the students were heavily relied on the meta-cognitive strategy. Furthermore, they showed that there is a low positive significant correlation between learners' critical thinking ability and their overall use of reading strategies. The also showed that males enjoy a higher level of critical thinking ability was higher comparing the females.

Rafi (2012) studied the influence of critical pedagogy on critical thinking ability through teaching English essay writing. To this end, 53 English Language Teachers and 34 Civil Superior Services (CSS) students were selected as the subjects of the study. the findings of his study revealed a marked difference (in the performance of English language teachers in the result of critical thinking instructions into the composition of English Essay Writing. Moreover, a significant difference was found between Post-test I and II among the CSS students. Hence, Rafi (2012) argues that incorporating critical thinking in teaching English Essay Writing improve writing ability of the students.

Lowy (2013) made an investigation on the relationship between and among learning styles, critical thinking aptitudes, and immersion learning in physician assistant students. To this end, she selected 137 Physician Assistant students as subjects who answered to several questionnaires of learning style inventory, the Gregorc Style Delineator, and a critical thinking aptitude test, as well as the Health Science Reasoning Test. She divided the subjects into two groups of preclinical PA students' and 'clinical PA students'. Hence, the results obtained from both instruments were compared in terms of associations between immersion clinical experiences and learning style preferences and critical thinking aptitudes. The results of her study indicated that "the PA students were preferentially concrete sequential learners with moderate to strong critical thinking aptitudes" (Lowy, 2013, p. 9). She also found that there were no significant differences between preclinical and clinical PA students with respect to learning styles or overall critical thinking aptitudes; however, significant differences were found between the two groups in terms of critical thinking. She argues that immersion learning did not influence learning style preferences.

KhodaeBalestane, Hashemnezhad, and Javidi (2013) made an investigation on the relationship between Iranian EFL learners' thinking styles and their language learning strategies. To this end, they selected 251 Iranian EFL learners majoring English in Azad universities of Uremia and Tabriz. The subjects were asked to fill out two questionnaires on language learning strategies and Thinking Styles Inventory. The result of their study indicated to a statistically significant relationship between the two sets of measures. In effect, it was found that thinking styles and language learning strategies have positive correlation with gender.

\section{Methodology}

\subsection{Participants of the Study}

The research sample was 60 EFL students studying in Payam Noor University of Khoy who were randomly selected through stratified sampling in the whole population-i.e. the 150 EFL students—were divided into two sub-groups of females with 90 students and males with 60 students, then 30 ones were selected randomly from 
The relationship between critical thinking skills, language learning strategies, and thinking styles

each subgroups in order to include 30 females and 30 males. The population of the study was both females and males with the range of age between 21 and 25. It is worth emphasizing that the participants were selected randomly through stratified sampling method in which the junior students were selected as the subjects of the study. Hence, the population out of them the subjects was selected were EFL students studying English in Payame Noor University. It is worth emphasizing that the baseline for selecting the Payame Noor University's students as the population of the study was convenience as well as diversity to allow for a broad perspective on desired purposes. Furthermore, the students were homogeneous in terms of the native language as well as in terms of the language courses and the amount of credit hours presented to them.

In a nutshell, the participants were 60 Iranian EFL students studying English in Payame Noor university of Khoy. The selected sample of the study was similar as the population in terms of native language, language courses as well as amount of credit hours they went through. Furthermore, the selected participants allow for a broad perspective to meet the purposes of the study.

\subsection{Instrumentations}

Instruments in this study were three sets of questionnaires, namely, The Sternberg and Wagner (1991) thinking styles inventory questionnaire, California critical thinking questionnaire as well as Oxford's (1990) language learning strategies. The Sternberg and Wagner (1991) thinking styles inventory questionnaire composed of 65 items with a Likert scale presentation (i.e. the students select an item as 1 . Never, 2. Sometimes, 3. Often, 4. Usually, and 5. Always for each items). The Sternberg and Wagner (1991) thinking styles inventory questionnaire was proved to be reliable and valid (Zhang, 2008).

The California critical thinking skill test is composed of 35 items--1-5 target interpretation , 6-9 analysis , 10-13 evaluation , 14-24 inference, and 25-35 explanation which the students have to select the answer among the multiple choices presented to them. It was repeatedly discussed by many researchers that the questions of The California critical thinking skill test is enough reliable as a research tool and correlated with test theoretical structure in which all subscales measured a single construct (Critical thinking). Furthermore, based on the review of literature, The California critical thinking skill test is able to distinguish between the persons with different level's critical thinking (e.g. Khalili \& Soleimani, 2003; Williams, Glasnapp, Tilliss, Osborn, Wilkins, Mitchell, Kershbaum, \& Schmidt, 2003). While, the Oxford's (1990) language learning strategies questionnaire is composed of 60 items in the form of likert scale as the one mentioned about the Sternberg and Wagner's (1991) questionnaire. The Oxford's (1990) language learning strategies questionnaire was highly reliable and valid (Mohammadi1 \& Alizadeh, 2014; Park, 2011).

In fact, the three sets of questionnaires - Sternberg and Wagner (1991) thinking styles and California critical thinking questionnaire as well as Oxford's (1990) language learning strategies-were selected as the instruments to gather data. The questionnaires were presented to the subjects to be filled out. The answers given by the students were coded and put in SPSS. The data were analyzed in terms of correlation using Spearman Rho statistic. We use spearman rho statistic since this test is utilized in analyzing the non-parametric data to determine the existence or non-existence of any correlation among the sub-tests.

\subsection{Research Procedures}

In conducting the present study, the 60 Iranian EFL students (30 females and 30 males) who were studying English in Payamenoor university of Khoy were selected using random sampling method through the stratified sampling technique in order to guarantee the inclusion of 30 students of each gender. The selected subjects were asked to fill out the three sets of questionnaires which were presented to them. In fact, the subjects filled out the three sets of questionnaires of The Sternberg and Wagner (1991) thinking styles inventory questionnaire, California critical thinking questionnaire as well as Oxford's (1990) language learning strategies. The California critical thinking questionnaires were scored based on the key which indicates to the right or wrong answers, the 
Alimirzaloo, E., \& Hashemnezhad, H.

other two questionnaires-The Sternberg and Wagner (1991) thinking styles inventory questionnaire and Oxford's (1990) language learning strategies-were scored based on the choice selected by the students which in The Sternberg and Wagner (1991) thinking styles composed of five alternatives equal to synthesis, idealist, pragmatist, analyst and realist based on the first, second, third, fourth or fifth choices, respectively; and in the Oxford's (1990) language learning strategies, the choices are comparable to the memory, cognitive, compensation, metacognitive, and socio-affective based on the choices selected by the students. The gathered data were coded, summarized and tabulated. The data were put into the SPSS 22 software in order to determine the association between and among thinking styles, learning strategies and critical thinking of the Iranian EFL students. To this end, Spearman's rank order correlation (Rho) statistic was run.

\section{Results}

This section is provided under three subsections of critical thinking, thinking styles, and learning strategies as well their relationships with each variable. Furthermore, the result section sheds light on the role of gender of each these variables.

\subsection{Critical Thinking}

It was mentioned that $60 \mathrm{EFL}$ students were the participants of the study who were asked to response to the California Critical Thinking Questionnaire. The following sheds light on the performances of the subjects on the critical thinking test.

\section{Table 1}

Performances of the Participants in the California Critical Thinking Test

\begin{tabular}{lc}
\hline \multicolumn{1}{c}{ Items } & Value \\
\hline Number of participants & 60 \\
Mean & 9.13 \\
Median & 10.00 \\
Mode & 4.00 \\
Std. Deviation & 3.86 \\
Minimum & 4.00 \\
Maximum & 18 \\
\hline
\end{tabular}

As the table shows the California critical thinking test shows the mean score of 9.13 , median of 10 and mode of 4. It is worth mentioning that the mode of scores was equal to the minimum score. Moreover, the participants showed the maximum score of 18 and the standard deviation of 3.86 which shows the dispersion of the scores of the participants from the mean score.

Table 2

Critical thinking and Gender

\begin{tabular}{llll}
\hline & & Critical thinking & Gender \\
\hline Critical thinking & Spearman correlation & 1 & $-0.46(* *)$ \\
& Sig. (2-tailed) & & 0.000 \\
& $\mathrm{~N}$ & 60 & 60 \\
\hline
\end{tabular}

Note. ${ }^{* *}$. Correlation is significant at the 0.01 level (2-tailed).

As the table shows the critical thinking and gender has a significant relationship' hence, it seems that gender plays a significant role on the critical thinking level of the subjects. Effectively, the female subjects had better performances on the critical thinking.

\subsection{Language Learning Strategies}

The second questionnaire which was answered by the subjects were Oxford's language learning strategies. It 
The relationship between critical thinking skills, language learning strategies, and thinking styles

was mentioned that the language learning strategies test which was utilized in this study has composed of five alternatives comparable with the strategies the subjects inclined to. The following table illustrates the performances of the subjects in this test.

Table 3

Language Learning Strategies and Performances of the Participants

\begin{tabular}{llllll}
\hline & $\mathrm{N}$ & Minimum & Maximum & Mean & Std. Deviation \\
\hline Never & 60 & 00.00 & 18.00 & 5.60 & 4.92 \\
Sometime & 60 & 4.00 & 34.00 & 11.80 & 7.18 \\
Usually & 60 & 1.00 & 27.00 & 11.86 & 6.93 \\
Often & 60 & 9.00 & 27.00 & 16.46 & 4.82 \\
Always & 60 & 1.00 & 25.00 & 14.26 & 6.96 \\
\hline
\end{tabular}

The table shows the minimum, maximum, mean and standard deviation of the diverse choices. As it shows the first choice had the mean of 5.60, the second one, the mean of 11.80, the third one the mean of 11.86, the fourth one the mean of 16.46 and the fifth one the mean of 14.26. A look at the table shows that the fourth choice had the most selection by the subjects.

This study also tries to determine the correlation between language learning strategies and gender. To this end, Spearman Correlation Coefficient was run in the SPSS22 and the following results were achieved.

Table 4

Language Learning Strategies and Gender

\begin{tabular}{llll}
\hline & & Language Learning Strategies & Gender \\
\hline Language Learning Strategies & Spearman correlation & 1 & 0.1 \\
& Sig. (2-tailed) & & 0.44 \\
& $\mathrm{~N}$ & 60 & 60 \\
\hline
\end{tabular}

The result of the Spearman correlation shows that gender plays a neutral role on the language learning strategies of the subjects.

\subsection{Thinking Styles}

The third questionnaire which was answered by the participants was The Sternberg and Wagner (1991) thinking styles inventory questionnaire. This questionnaire as the previous one was Likert scale with five alternatives of never, sometimes, usually, often and always equal to synthesis, idealist, pragmatist, analyst and realist respectively. The following table shows the performances of the subjects in this test:

\section{Table 5}

Thinking Styles and Performances of the Participants

\begin{tabular}{llllll}
\hline & $\mathrm{N}$ & Minimum & Maximum & Mean & Std. Deviation \\
\hline Never & 60 & 1 & 10.00 & 3.86 & 2.23 \\
Sometime & 60 & 4.00 & 29.00 & 13.33 & 7.47 \\
Usually & 60 & 7 & 30.00 & 17.20 & 7.61 \\
Often & 60 & 9.00 & 33.00 & 20.46 & 6.59 \\
Always & 60 & 00.00 & 23.00 & 10.20 & 6.06 \\
\hline
\end{tabular}

The table shows that the fourth one was the most selected choice by the subjects which indicated to the prominence of analysis thinking style among the subjects. Effectively, the first choice which is comparable to the synthesis orientation was the least selected choice. Furthermore, the first and the fifth choices which are comparable to the idealist and realist orientations were neither high nor low in the participants.

This study also tries to determine the relations between thinking styles and the gender of the subjects. To this end, as the previous sections, Spearman correlation was run in the SPSS 22 which resulted into significant 
Alimirzaloo, E., \& Hashemnezhad, H.

relation. It means that gender a determining factor on the tendency of the critical thinking styles of the subjects.

Table 6

Thinking Styles and Gender

\begin{tabular}{llll}
\hline & & Thinking Styles & Gender \\
\hline Thinking Styles & Spearman correlation & 1 & $-0.37(* *)$ \\
& Sig. (2-tailed) & & 0.03 \\
& $\mathrm{~N}$ & 60 & 60 \\
\hline
\end{tabular}

Note. ${ }^{* *}$. Correlation is significant at the 0.01 level (2-tailed).

Hence, the correlation between thinking styles and gender is significant at 0.01 level.

\subsection{Critical Thinking and Language Learning Strategies}

One of the aims of the present study was to determine the relationship between critical thinking and language learning strategies of the Iranian EFL students. Effectively, the results of the both tests were put in the SPSS 22 and were analyzed utilizing Spearman Rho correlation Coefficient. The following table sheds light on the results of the Spearman correlation.

\section{Table 7}

Critical Thinking and Language Learning Strategies: Correlation Coefficient

\begin{tabular}{llll}
\hline & & Critical Thinking & Language Learning Strategies \\
\hline Critical Thinking & Spearman correlation & 1 & $0.33(* *)$ \\
& Sig. (2-tailed) & & 0.08 \\
& $\mathrm{~N}$ & 60 & 60 \\
\hline
\end{tabular}

**. Correlation is significant at the 0.01 level (2-tailed).

As the table shows there is a significant relation between critical thinking and language learning strategies. Effectively, the results of the correlation were significant at 0.01 level. It means that the level of critical thinking and language learning strategies have positive and direct relationships.

\subsection{Critical Thinking and Thinking Styles}

The second aim of the present study was to determine the relationship between critical thinking and thinking styles. To this end, the results of the two tests of California Critical Thinking and Sternberg and Zhang (1991) thinking styles inventory questionnaire were put on the SPSS 22 and Correlation Coefficient was run which resulted into non-significant relationship between the two variables.

Table 8

Critical Thinking and Thinking Styles: Correlation Coefficient

\begin{tabular}{llll}
\hline & & Critical Thinking & Thinking Styles \\
\hline Critical Thinking & Spearman correlation & 1 & 0.17 \\
& Sig. (2-tailed) & & 0.17 \\
& $\mathrm{~N}$ & 60 & 60 \\
\hline
\end{tabular}

Hence, the level of critical thinking and the tendencies of the thinking styles in the Iranian EFL students seem to be uncorrelated.

\subsection{Thinking Styles and Language Learning Strategies}

The third aims of the present study were to determine the relationship between thinking styles and language learning strategies. To this end, in the same vein with the previous sections Spearman Correlation Coefficient was run as the table shows: 
The relationship between critical thinking skills, language learning strategies, and thinking styles

Table 8

Language Learning Strategies and Thinking Styles: Correlation Coefficient

\begin{tabular}{llll}
\hline & & Critical Thinking & Thinking Styles \\
\hline Critical Thinking & Spearman correlation & 1 & -0.1 \\
& Sig. (2-tailed) & & 0.93 \\
& $\mathrm{~N}$ & 60 & 60 \\
\hline
\end{tabular}

As the table shows there is a non-significant relationship between languages learning strategies and thinking styles. It seems that language learning strategies and critical thinking had a similar behavior in which both of them had significant relationship with each other and non-significant relationship with thinking styles. The following section summarizes the results and provides some bases to pave the way for answering the raised questions of the study.

\subsection{Critical Thinking, Thinking Styles and Language Learning Strategies}

One of the aims of this study was to determine the correlation among three variables of critical thinking, thinking styles and language learning strategies. The previous sections indicated that, on one hand, there is significant relationship between critical thinking and language learning strategies and on the other hand there is a significant relation between language learning strategies and thinking styles; however, a non-significant relation was found between critical thinking and thinking styles. In order to have more dependable results multiple regression analysis was performed in SPSS 22 to determine the relation among these three variables. The following sheds light on the results of this statistic. Table 9 shows that there is a constant and relatively significant relation between the three variables.

\section{Table 9}

Critical Thinking, Language Learning Strategies and Thinking Styles: Multiple Correlation Coefficient

\begin{tabular}{lllll}
\hline Model & R & R Square & Adjusted R Square & Std. Error of the Estimate \\
\hline 1 & $0.479^{\mathrm{a}}$ & 0.229 & 0.202 & 3.44713 \\
\hline
\end{tabular}

Considering the results of the second table which was provided by the multiple regression analysis in SPSS shows that the relation between these three variables is significant.

Table 10

Critical Thinking, Language Learning Strategies and Thinking Styles: Multiple Correlation Coefficient

\begin{tabular}{lllllll}
\hline Model & & Sum of Squares & df & Mean Square & F & Sig. \\
\hline 1 & Regression & 201.617 & 2 & 100.809 & 8.484 & .001 \\
& Residual & 677.316 & 57 & 11.883 & & \\
& Total & 878.933 & 59 & & & \\
\hline
\end{tabular}

\section{Discussion}

The main thrust of the presents study was to determine the relationship between the three variables of critical thinking, language learning strategies and thinking styles. As the above sections of this chapter indicated the role of gender was also investigated in order to present more dependable results. It was shown that gender was a crucial factor for critical thinking and thinking styles. It may indicate the fact that critical thinking and thinking styles have something in common which are determined to some degree by the biological gender. Critical thinking is a complicated mental activity which demands higher levels of cognitive skills in dealing with diverse problems especially in solving problems, making decisions as well as making inferences. Mitrevski and Zajkov (2012, p. 14) argue that critical thinking demands the following:

Raising vital questions and problems, formulating them clearly and precisely; 
> Gathering and assessing relevant information, using abstract ideas to interpret it effectively;

$>$ Coming to well-reasoned conclusions and solutions, testing them against relevant criteria and standards;

$>$ Thinking open-mindedly within alternative systems of thought, recognizing and assessing, as need be, their assumptions, implications, and practical consequences;

$>$ Communicating effectively with others in figuring out solution to complex problems.

The aforementioned issues highlight the tenets of critical discourse analysis, but what its relation with gender is. Considering the review of literature shows that there are some differences between females and males in different problem solving tasks. For example, Graybill (1975) argue that gender plays a crucial role in problem-solving tasks, in which men outperform in logical thinking ability.

Considering the review of literature in terms of the relation between thinking styles and gender shows that men have the propensity to rely heavily on their right-hemisphere style items in processing information whereas women prefers an integrated style from the both hemispheres in processing information. Hence, the both critical thinking and thinking styles are the cognitive-related issues which have significance relation with gender.

Language learning strategies, according to Oxford (1990), are particular actions taken by the subjects in order to resolve their learning task and make it easier, faster, and adaptable to new situations of language learning and use. Effectively, language learning strategies seem to be among the adventitious characteristics of human beings which are learnable and not natural. Literature review shows complicated findings regarding the relation between gender and language learning strategies in which some studies indicated to significant relations (e.g. Dongyue, 2004; Kaylani, 1996) and in some others the blurred results were achieved (e.g. Dadour \& Robbins, 1996). As it was mentioned non-significant relationship was found between language learning strategies and gender.

One of the purposes of the present study was to determine the relationships between critical thinking and language learning strategies which resulted into significant correlation. The gathered data indicated that $80 \%$ of the subjects used the compensation and socio-affective strategies. Furthermore, the data showed that these $80 \%$ had the highest level of critical thinking. The results of the Spearman correlation coefficient also indicated to the significant relationship between these two variables. In effect, the cognitive strategy was not selected by the students at all. The memory strategy was selected by $7 \%$ of the subjects and the metacognitive strategy by $13 \%$ of the subjects. Effectively, the subjects with the memory and metacognitive strategy's preferences were also achieved the lowest score in the critical thinking test. Hence, the results of the relation between critical thinking and language learning strategies are in harmony with the findings of Nikoopour, Farsani and Nasiri (2011) who argue that there is a significant relationship between language learning strategies and critical thinking. However, the findings of the present study, contrary to the findings of Nikoopour, Farsani and Nasiri (2011), found a positive and strong relationship between critical thinking and compensation and socio-affective strategies and also a non-significant relationship between memory, cognitive and metacognitive language learning strategies. Furthermore, the results of the study contradicted the findings of Nosratinia, Asiabar, and Sarabchian (2014) who argue that the memory strategy is the best indicator of critical thinking since memory strategy was not selected at all by the participants of the present study.

The first question of this study was

\section{Are there any relationship between critical thinking and language learning strategies?}

This study was answered and the first hypothesis which states there is a relationship between critical thinking and language learning strategies was supported.

The second purpose of this study was to determine the relationship between critical thinking and thinking styles of the Iranian EFL Students. In terms of the five choices of the thinking styles which are comparable with 
The relationship between critical thinking skills, language learning strategies, and thinking styles

the five thinking styles of synthesis, idealist, pragmatist, analyst and realist, it was found that $40 \%$ of the subjects were analyst, $20 \%$ pragmatist, $13 \%$ idealist, $13 \%$ synthesis and $7 \%$ realist. Effectively, the highest score on critical thinking test was related to the subjects whose thinking style' preference was revealed to be idealist. Hence, in determining the correlation between critical thinking and thinking style, Spearman correlation coefficient was run which resulted into non-significant relation between the variables. Hence, the result of this part of the study contradicted the findings of Abdi (2012) who argues that that there is a significance relationship between thinking styles and critical thinking skills.

The second question of this study was:

\section{Are there any relationship between critical thinking and thinking styles?}

This study was also answered and through which the second hypothesis which states there is a relationship between critical thinking and thinking styles was rejected.

The third purpose of the study was to determine the relationship between language learning strategies and thinking styles. To this end, Spearman Correlation Coefficient was run which showed that there is a significant and positive relationship between thinking styles and language learning strategies. Hence, the results of this study is in line with the findings of Ahmadi, Gorjani, and Pazhakh (2014) who argue that there is a significance relationship between thinking styles and use of language learning strategies. Moreover, this study supported the findings of KhodaeBalestane, Hashemnezhad, and Javidi (2013) whose study indicated to a statistically significant relationship between the two sets of measures. In effect, it was found that thinking styles and language learning strategies have positive correlation with gender.

Hence, the third question of this study was

\section{Are there any relationship between thinking styles and language learning strategies?}

This study was answered and the third hypothesis which states that there is a relationship between language learning strategies and thinking styles was supported.

Finally the fourth question was to provide some bases for answering the forth question:

\section{Are there any relationship between thinking styles, critical thinking and language learning strategies?}

The results of the study indicated that critical thinking has a significant, direct and positive relation with learning strategies and learnings strategies has also a significant and positive relation with the thinking styles; whereas, non-significant relation was found between critical thinking and thinking style. Hence, in order to answer the fourth question multiple regression analysis was performed which resulted into significant relationship among the three variables. Effectively, the fourth hypothesis which stated there is a relationship between critical thinking, language learning strategies and thinking styles was finally supported.

\subsection{Pedagogical Implications}

This study as many studies on the field of education have some implications for teaching and learning. There is no doubt regarding the significant role of critical thinking on fostering the academic achievements of the students Furthermore, Critical thinking is fundamental in literacy skills. Furthermore, thinking styles as the third variables of the present study seem to influence the process of language learning especially in the literacy skills.

Considering the aforementioned issues, there is no doubt regarding the significant implications of this study for language teachers, language learners as well as for course designers or curriculum developers to implement the results of this study in the courses they presented to the learners in order to design and develop their materials in course with fostering the critical thinking, thinking styles and language learning strategies which seem to be indicators of learning achievements which especially influence the learners' literacy skills. Hence, 
Alimirzaloo, E., \& Hashemnezhad, H.

these three variables need to be fostered simultaneously since there are significant relationships between them which may mutate the academic life of the students and especially the language learners .

\section{References}

Abdi, A. (2012). A study on the relationship of thinking styles of students and their critical thinking skills. Procedia - Social and Behavioural Sciences, 47, 1719-1723. http://dx.doi.org/10.1016/j.sbspro.2012.06.889

Bailin, S., Case, R., Coombs, J. R., \& Daniels, L. B. (1999). Conceptualizing critical thinking. Journal of Curriculum Studies, 31(3), 285-302. http://dx.doi.org/10.1080/002202799183133

Bransford, J. D., Brown, A. L. \& Cocking, R.R. (2000). How people learn. Washington, D.C.: National Academy Press.

Cano, J. (1993). An assessment of the level of cognitive performance and critical thinking ability of selected agricultural education students. Journal of Agricultural Education, 34(2), 25-30. http://dx.doi.org/10.5032/jae.1993.02025

Cano, J. (1999). The relationship between learning style, academic major, and academic performance of college students. Journal of Agricultural Education, 40(1), 30 - 37. http://dx.doi.org/10.5032/jae.1999.01030

Cano, J., \& Garton, B. L. (1994). The relationship between agriculture pre-service teachers' learning styles and performance in a methods of teaching agriculture course. Journal of Agricultural Education, 35(2), 6-10. http://dx.doi.org/10.5032/jae.1994.02006

Cano, J., \& Martinez, C. (1991). The relationship between cognitive performance and critical thinking abilities among selected agricultural education students. Journal of Agricultural Education, 32(1), 24-29. http://dx.doi.org/10.5032/jae.1991.01024

Cano, J., \& Metzger, S. (1995). The relationship between learning style and levels of cognition of instruction of horticulture teachers. Journal of Agricultural Education, 23(2), 36-42. http://dx.doi.org/10.5032/jae.1995.02036

Curry, L. (1983). An organization of learning styles theory and constructs. Paper presented at the Annual Meeting of the American Educational Research Association, Montreal, Quebec.

Dadour, E. S., \& Robbins, J. (1996). University-level studies using strategy instruction to improve speaking ability in Egypt and Japan. In R. Oxford (Ed.), Language learning strategies around the world: Cross-cultural perspectives (pp. 157-166). Manoa: University of Hawaii Press.

Dongyue, L. (2004). EFL proficiency, gender and language learning strategy use among a group of Chinese technological institute English majors. Arecls E-Journal, 1(A5).

Dyer, J. E. (1995). Effects of teaching approach on achievement, retention, and problem solving ability of Illinois agricultural education students with varying learning styles. Unpublished doctoral dissertation, University of Illinois at Urbana-Champaign.

Dyer, J. E., \& Osborne, E. W. (1996a). Effects of teaching approach on achievement of agricultural education students with varying learning styles. Journal of Agricultural Education, 37(3), 43-51. http://dx.doi.org/10.5032/jae.1996.03043

Dyer, J. E., \& Osborne, E. W. (1996b). Effects of teaching approach on problem solving ability of agricultural education students with varying learning styles. Journal of Agricultural Education, 37(4), 38-45. http://dx.doi.org/10.5032/jae.1996.04038

Ennis, R. H. (1985). A logical basis for measuring critical thinking skills. Educational Leadership, 43(2), 44-48.

Facione, P. A. (1990). Critical thinking: A statement of expert consensus for purposes of educational assessment and instruction. Millbrae: The California Academic Press.

Garton, B. L., Spain, J. M., Lamberson, W. R., \& Spiers, D. E. (1999). Learning styles, teaching performance and student achievement: A relational study. Journal of Agricultural Education, 40(3), 11-20. http://dx.doi.org/10.5032/jae.1999.03011

Graybill, L. (1975). Sex differences in problem solving ability. Journal of Research in Science Teaching, 12, 341-346. http://dx.doi.org/10.1002/tea.3660120404 
The relationship between critical thinking skills, language learning strategies, and thinking styles

Grigorenko, E. L., \& Sternberg, R. J. (1995). Thinking styles. In D. Saklofske \&M. Zeidner (Eds.), International handbook of personality and intelligence (pp. 205-229). New York, NY: Plenum. http://dx.doi.org/10.1007/978-1-4757-5571-8_11

Halpern, D. F. (1998). Teaching critical thinking for transfer across domains: Dispositions, skills, structure training, and metacognitive monitoring. American Psychologist, 53(4), 449-455. http://dx.doi.org/10.1037/0003-066X.53.4.449

Kaylani, C. (1996), The influence of gender and motivation of EFL learning strategy use in Jordan. In R. Oxford, (Ed.) Language learning strategies around the world: Cross-cultural perspectives (pp. 75-88). Honolulu: University of Hawai'i: Second Language Teaching and Curriculum Center.

Khalili, H, \& Soleimani, M. (2003). Determining the trust, credibility and norm scores of the California Critical Thinking Skills Test-Form B (TSTCC-B). Journal of Babol University of Medical Sciences, 2, 84-90.

Khodae Balestane, M., Hashemnezhad, H., \& Javidi, S. (2013). The relationship between language learning strategies and thinking styles of Iranian EFL learners. International Journal of Research Studies in Language Learning, 2(4), 3-19. http://dx.doi.org/10.5861/ijrsll.2012.186

Lewis, A., \& Smith, D. (1993). Defining higher order thinking. Theory into Practice, 32(3), 131-137. http://dx.doi.org/10.1080/00405849309543588

Lipman, M. (1988). Critical thinking - What can it be? Educational Leadership, 46(1), 38-43.

Lowy, N. (2013). Learning styles, critical thinking aptitudes, and immersion learning in physician assistant students. Unpublished Ph. D. thesis, Seton Hall University, NY, USA. Retrieved from http://scholarship.shu.edu/cgi/viewcontent.cgi?article=2929\&context=dissertations

McPeck, J. E. (1990). Critical thinking and subject specificity: A reply to Ennis. Educational Researcher, 19(4), 10-12. http://dx.doi.org/10.3102/0013189X019004010

Miller, A. (1987). Cognitive styles: An integrated model. Educational Psychology, 7(4), 251-268. http://dx.doi.org/10.1080/0144341870070401

Mitrevski, B., \& Zajkov, O. (2012). Physics lab, critical thinking and gender differences. Macedonian Physics Teacher, 48, 13-18.

Mohammadi, H., \& Alizadeh, K. (2014). An investigation of reliability and validity of strategy inventory for language learning among Iranian university students. International Journal of English Language Teaching, 1(2), 53-63. http://dx.doi.org/10.5430/ijelt.v1n2p53

Mohammadi, S. N., Heidari, F., \& Niry, N. D. (2012). The Relationship between critical thinking ability and reading strategies used by Iranian EFL learners. English Language Teaching, 5(10), 192-201. http://dx.doi.org/10.5539/elt.v5n10p192

Myers, B. E., \& Dyer, J. E. (2006). The influence of student learning styles on critical thinking skills. Journal of Agricultural Education, 47(1), 43-52. http://dx.doi.org/10.5032/jae.2006.01043

Naiman, N., Frohlich, M., Stern, H. H., \& Todesco, A. (1978). The good language learner. Research in Education Series. Toronto: Ontario Institute for studies in Education.

Negari, G. M., \& Solaymani, M. (2013). The relationship among autonomy, thinking styles and language learning strategy use in Iranian EFL learners. International Journal of Linguistics, 5(1), 332-347. http://dx.doi.org/10.5296/ijl.v5i1.3320

Nikoopour, J., Farsani M., \& Nasiri, M. (2010). On the relationship between critical thinking and language learning strategies among Iranian EF learners. Journal of Technology and Education, 3,195-200.

O’Malley, J. M., \& Chamot, A. U. (1990). Learning strategies in second language acquisition. New York: the Press Syndicate of University of Cambridge. http://dx.doi.org/10.1017/CBO9781139524490

Oxford, R., Lavin, R., \& Crookall, D. (1989). Language learning strategies, the communicative approach, and their classroom implications. Foreign Language Annals, 22, 29-39. http://dx.doi.org/10.1111/j.1944-9720.1989.tb03139.x

Oxford, R. L. (1990). Language learning strategies: What every teacher should know. Boston: Heinle \& Heinle.

Park, G. P. (2011). The validation process of the SILL: A confirmatory factor analysis. English Language Teaching, 4(4), 21-27. http://dx.doi.org/10.5539/elt.v4n4p21

Rafi, M. S. (2012). Promoting critical pedagogy in language education. International Research Journal of Arts \& 
Humanities, 37, 63-73.

Ricketts, J. C. (2003). The efficacy of leadership development, critical thinking dispositions, and student academic performance on the critical thinking skills of selected youth leaders. Unpublished doctoral dissertation, University of Florida, Gainesville.

Riding, R. J., \& Cheema, I. (1991). Cognitive styles - An overview and integration. Educational Psychology, 11(3 \& 4), 193-215. http://dx.doi.org/10.1080/0144341910110301

Rubin, J. (1987). Learner strategies: Theoretical assumptions, research history and typology. In A. L. Wenden \& J. Rubin (Eds.), Learner strategies in language learning (pp. 15-30). Englewood Cliffs, NJ: Prentice-Hall.

Ruggiero V. R. (1989). Critical thinking: Supplement to becoming a master student. Rapid City: College Survival Inc.

Sadler-Smith, E. (2009). A duplex model of cognitive style. In L. F. Zhang \& R. J. Sternberg (Eds.), Perspectives on the nature of intellectual styles (pp. 3-28). New York, NY: Springer Publishing Company.

Sternberg, R. J. (1986). Critical thinking: Its nature, measurement, and improvement. Retrieved from http://eric.ed.gov/PDFS/ED272882.pdf

Sternberg, R. J. (1988). Mental self-government: A theory of intellectual styles and their development. Human Development, 31, 197-224. http://dx.doi.org/10.1159/000275810

Sternberg, R. J. (1997). Thinking styles. New York: Cambridge University Press. http://dx.doi.org/10.1017/CBO9780511584152

Thayer-Bacon, B. J. (2000). Transforming critical thinking: Thinking constructively. New York: Teachers College Press.

Watson, G., \& Glaser, E. (1980). Watson-Glaser Critical Thinking Appraisal. SanAntonio: Psychological Corporation.

Wenden, A. L. (1987). Conceptual background and utility. In A. L. Wenden \& J. Rubin (Eds.), Learner strategies in language learning (pp. 3-13). Englewood Cliffs, NJ: Prentice-Hall.

Williams, K. B., Glasnapp. D. R., Tilliss, T. S., Osborn, J., Wilkins, K., Mitchell, S., Kershbaum W., \& Schmidt, C. (2003). Predictive validity of critical thinking skills for initial clinical dental hygiene performance. US National Library of Medicine National Institutes of Health, 67(11), 1180-1192.

Zhang, L. F., \& Sternberg, R. J. (2005). A threefold model of intellectual styles. Educational Psychology Review, 17(1), 1-53. http://dx.doi.org/10.1007/s10648-005-1635-4

Zhang, L. F., \& Sternberg, R. J. (2006). The nature of intellectual styles. Mahwah: Lawrence Erlbaum.

Zhang, L. F., Sternberg, R. J., \& Rayner, S. (2012). Handbook of intellectual styles. New York: Springer. 